Katsuya Mikawa MD, Kahoru Nishina MD, Nobuhiro Maekawa MD, Yumiko Takao MD, Migiwa Asano MD, Hidefumi Obara MD

\title{
Attenuation of the catecholamine response to tracheal intubation with oral clonidine in children
}

We conducted a prospective, randomized, double-blind, controlled clinical trial to examine (I) whether plasma catecholamine $(C A)$ concentrations increased in response to tracheal intubation in children, and (2) the effects of clonidine on the $C A$ responses. Sixty children (ASA physical status I) aged 7-13 $y r$ were allocated to one of three groups ( $n=20$ for each group): diazepam $0.4 \mathrm{mg} \cdot \mathrm{kg}^{-1}$ (active control), clonidine 2 $\mu \mathrm{g} \cdot \mathrm{kg}^{-1}$, or clonidine $4 \mu \mathrm{g} \cdot \mathrm{kg}^{-1}$ po. These agents were administered $105 \mathrm{~min}$ before induction of anaesthesia followed by oral atropine $0.03 \mathrm{mg} \cdot \mathrm{kg}^{-1}$ given $60 \mathrm{~min}$ before anaesthesia which was induced with thiamylal $5 \mathrm{mg} \cdot \mathrm{kg}^{-1}$ and tracheal intubation was facilitated with vecuronium $0.2 \mathrm{mg} \cdot \mathrm{kg}^{-1} . \mathrm{La}$ ryngoscopy, lasting $30 \mathrm{sec}$, was attempted two minutes after administration of the induction agents. Serial values for blood pressure, heart rate, and venous plasma $C A$ concentrations were compared among the three groups and with the respective preinduction measurements. Children receiving diazepam or clonidine $2 \mu \mathrm{g} \cdot \mathrm{kg}^{-1}$ showed remarkable increases in systolic and diastolic blood pressures, heart rate, and plasma $C A$ concentrations in response to tracheal intubation $(P<0.05)$. The increases were similar for the two regimens. These haemodynamic and $C A$ changes were smaller in children receiving clonidine $4 \mu \mathrm{g} \cdot \mathrm{kg}^{-1}(P<0.05)$. The haemodynamic responses were positively correlated with the $C A$ responses. These findings indicate that tracheal intubation following rapid sequence in-

\section{Key words}

ANAESTHESIA: paediatric;

INTUBATION, TRACHEAL: complications;

SYMPATHETIC NERVOUS SYSTEM: $\alpha_{2}$-adrenoceptor agonist; HORMONES: catecholamines.

From the Department of Anaesthesiology, Kobe University School of Medicine, Kusunoki-cho 7, Chuo-ku, Kobe 650, Japan.

Address correspondence to: Dr. K. Mikawa.

Accepted for publication 2nd June, 1995. duction of anaesthesia in children provokes a reflex increase in sympathetic activity characterized by increased plasma $C A$ concentrations, and that attenuation of the cardiovascular changes with a high oral dose of clonidine may be due to suppression of the increase in sympathetic activity evoked by the intubation.

Au cours d'une étude contrôlée prospective randomisée et à double insu, les auteurs examinent 1) si la concentration plasmatique des catécholamine ( $C A)$ augmente chez les enfants en réponse à lintubation de la trachée et 2) quels sont les effets de la clonidine sur la réponse des CA. Soixante enfants ( $A S A$ 1) âgés de 7 à 13 ans sont répartis en trois groupes ( $n=20$ pour chacun) pour recevoir: diazepam $0,4 \mathrm{mg} \cdot \mathrm{kg}^{-1}$ (contrôle actif), clonidine $2 \mu \mathrm{g} \cdot \mathrm{kg}^{-1}$, ou clonidine $4 \mu \mathrm{g} \cdot \mathrm{kg}^{-1}$ po. Ces agents sont administrés $105 \mathrm{~min}$ avant l'induction de l'anesthésie et sont suivis d'atropine $0,03 \mathrm{mg} \cdot \mathrm{kg}^{-1}$ po 60 min avant celle-ci. L'anesthésie est induite avec du thiamylal $5 \mathrm{mg} \cdot \mathrm{kg}^{-1}$ et la trachée est intubée après l'administration de vécuronium $0,2 \mathrm{mg} \cdot \mathrm{kg}^{-1}$. La laryngoscopie d'une durée de 30 sec est tentée deux min après l'administration des agents dinduction. Les mesures en série de la pression artérielle, de la fréquence cardiaque et de la concentration plasmatique des CA sont comparées entre les trois groupes et avec les valeurs respectives précédant linduction. Les enfants qui reçoivent diazépam ou clonidine $2 \mu \mathrm{g} \cdot \mathrm{kg}^{-1}$ manifestent des augmentations importantes des pressions systolique et diastolique, de la fréquence cardiaque et de la concentration des $C A$ en réponse à lintubation de la trachée $(P<0,05)$. Les augmentations constatées ne different pas entre ces deux traitements. Les changements hémodynamiques et de $C A$ sont moindres chez les enfants qui reçoivent de la clonidine $4 \mu \mathrm{g} \cdot \mathrm{kg}^{-l}(P<0,05)$. La réponse hémodynamique a une corrélation positive avec celle des $C A$. Ces données montrent que l'intubation de la trachée après une induction à séquence rapide provoque chez l'enfant une augmentation réflexe de l'activité sympathique caractérisée par une augmentation des CA plasmatiques, et que l'atténuation de la réponse cardiovasculaire avec une dose orale élevée de clonidine peut être due à la suppression de l'augmentation de l'activité sympathique évoquée par lintubation. 
Laryngoscopy and tracheal intubation often provoke hypertension and tachycardia in children as well as in adults. ${ }^{1,2}$ Although it is well known that these haemodynamic changes are associated with the release of catecholamines (CA) in adults, ${ }^{3-5}$ no reports are available to date on the occurence of similar phenomena in children.

Clonidine, an $\alpha_{2}$ agonist, has been shown to be an effective premedicant in adults, providing preoperative sedation and reduction in the volatile anaesthetic requirement. ${ }^{6}$ Furthermore, the drug successfully attenuates the cardiovascular responses to tracheal intubation. ${ }^{6}$ This beneficial effect of clonidine is due probably to suppression of the increase in plasma CA concentrations. ${ }^{6}$ We have recently shown that oral clonidine premedication attenuated the haemodynamic changes following tracheal intubation in children. ${ }^{7}$ The aim of the current study was to examine (1) whether plasma CA concentrations increase in response to tracheal intubation in children as they do in adults, and (2) the effect of clonidine on the CA responses.

\section{Methods}

\section{Subjects}

After institutional approval and parental informed consent, we initiated a trial involving 60 children (inpatients of ASA physical status 1) aged from 7 to $13 \mathrm{yr}$ undergoing elective ophthalmological or otological surgery. They were randomly assigned to one of three groups ( 20 children per group); diazepam $0.4 \mathrm{mg} \cdot \mathrm{kg}^{-1}$ (active control), clonidine $2 \mu \mathrm{g} \cdot \mathrm{kg}^{-1}$, or clonidine $4 \mu \mathrm{g} \cdot \mathrm{kg}^{-1}$ in $0.15 \mathrm{ml} \cdot \mathrm{kg}^{-1}$ given orally in apple juice. Diazepam is a premedicant in routine use in our hospital. These agents were administered $105 \mathrm{~min}$ before the anticipated induction of anaesthesia. We used clonidine at this timing in our previous studies. ${ }^{7,8}$ Other investigators administered clonidine to adult patients $90-120 \mathrm{~min}$ before induction of anaesthesia. ${ }^{9,10}$ Diazepam at $0.3-0.5 \mathrm{mg} \cdot \mathrm{kg}^{-1}$ has been recommended to be administered $60-120 \mathrm{~min}$ before anaesthesia. ${ }^{11,12}$ All children also received atropine 0.03 $\mathrm{mg} \cdot \mathrm{kg}^{-1}$ po in $0.2 \mathrm{ml} \cdot \mathrm{kg}^{-1}$ apple juice $60 \mathrm{~min}$ before estimated induction of anaesthesia. Milk and solids were allowed until 9:00 p.m. before surgery. The patients were instructed to ingest a large volume of apple juice (10 $\mathrm{ml} \cdot \mathrm{kg}^{-1}$ ) three hours before induction of anaesthesia.

\footnotetext{
Haemodynamic measurements and blood sampling

A minimum of $90 \mathrm{~min}$ was allowed between oral preanaesthetic medication and entry into the operating room, where all children received nitrous oxide $\left(\mathrm{N}_{2} \mathrm{O}\right) 3$ $\mathrm{L} \cdot \mathrm{min}^{-1}$ and oxygen $3 \mathrm{~L} \cdot \mathrm{min}^{-1}$ via a mask for three minutes to provide analgesia ${ }^{13}$ during cannulation of the
}

right and left ant-cubital veins: one cannula was used for the administration of drugs and the other for blood collection to determine plasma CA concentrations. After the establishment of venous access, $\mathrm{N}_{2} \mathrm{O}$ was discontinued and the children breathed $100 \%$ oxygen for five minutes. Monitoring of systolic blood pressure (SBP), and diastolic blood pressure (DBP) with an automatic non-invasive blood pressure (BP) monitor (Pulsemate BX-5®, Nippon Colin, Tokyo, Japan) was begun. The BP cuff was placed on the same side of the upper extremity that used for drug infusion. The other side was used for cannulation for blood collection. Heart rate (HR) was monitored from lead II of the electrocardiogram. Immediately before the induction of anaesthesia, SBP, DBP, and HR were recorded and the first blood sampling (operating room baseline) was obtained by independent observers. Anaesthesia was then induced with thiamylal $5 \mathrm{mg} \cdot \mathrm{kg}^{-1}$ followed by vecuronium $0.2 \mathrm{mg} \cdot \mathrm{kg}^{-1}$ to facilitate tracheal intubation. Thus, the BP cuff did not preclude CA sampling or administration of the induction agents. Direct laryngoscopy was attempted two minutes after thiamylal and maintained for $30 \mathrm{sec}$. A shorter duration (e.g., $15 \mathrm{sec}$ ) of laryngoscopy was not employed, since this may cause automatic BP monitor (every one minute) to fail to record a peak haemodynamic change following intubation. The endotracheal tube was placed exactly within the last five seconds of laryngoscopy. All intubations were performed by the same individual (KM) who was blinded to the nature of the treatment. From the time of administration of thiamylal until five minutes after induction, ventilation was assisted or controlled using $1.5 \%$ (inspired) halothane and $50 \% \mathrm{~N}_{2} \mathrm{O}$ in oxygen, and end-tidal $\mathrm{PCO}_{2}$ was maintained between 4.2 and $5.1 \mathrm{kPa}$ (Capnomac Ultima, Datex Helsinki, Finland) via a catheter placed in the nostril from the induction of anaesthesia until the commencement of laryngosocopy. After insertion of the endotracheal tube, expired air was sampled from the T-piece connected to the tube. Further automatic readings of haemodynamic variables and blood samples (from the antecubital vein) for CA measurements were obtained by the independent observers $2,3,4$, and 5 min after administration of thiamylal. Serial values of DBP, SBP, HR, and plasma CA concentrations were compared among the three groups and with the respective preinduction measurements (operating room baseline) within the same study group.

\section{Catecholamine measurement}

Venous blood for measurement of plasma CA concentrations collected in lithium heparin tubes was centrigued within ten minutes at $0^{\circ} \mathrm{C}$. Plasma was separated and stored at $-70^{\circ} \mathrm{C}$ until the assay was performed by reverse phase high-performance liquid chromatography with elec- 
trochemical detection and an internal standard using the method described by Krstulovic, ${ }^{14}$ and by Causon et al. ${ }^{15}$ The lower limit of sensitivity of the method is 10 $\mathrm{pg} \cdot \mathrm{ml}^{-1}$. The intra- and inter-assay coefficients of variance were respectively $4.2 \%$ and $7.8 \%$ for epinephrine and $4.7 \%$ and $8.3 \%$ for norepinephrine (NE).

\section{Statistics}

Continuous variables of data were statistically analysed using repeated measures analysis of variance for intragroup comparison and using Student's $t$ test with Bonferroni correction for inter-group comparison. Differences were considered statistically significant at $P<0.05$. The strength of the relationship between haemodynamic changes and plasma CA changes was determined using Pearson's product correlation coefficient (r).

\section{Results}

There were no differences among the three groups with regard to age, weight, or haemodynamic variables measured in the ward (Table I).

Although baseline values of SBP, DBP, and HR seemed to be lower in children receiving clonidine 4 $\mu \mathrm{g} \cdot \mathrm{kg}^{-1}$ than in those given other regimens, there were no differences in these variables before induction among the three groups. Clonidine $4 \mu \mathrm{g} \cdot \mathrm{kg}^{-1}$ attenuated the marked BP and HR increases associated with tracheal intubation in children receiving diazepam or clonidine 2 $\mu \mathrm{g} \cdot \mathrm{kg}^{-1}$. In the latter two regimens, these haemodynamic changes were comparable (Figure 1 and Table II).

Plasma CA concentrations increased following tracheal intubation in the diazepam and the low-dose of clonidine groups. These increases were less marked in the highdose of clonidine group than in the groups receiving other regimens, in which the hormonal changes were similar to each other (Figures 2 and 3 and Table II).

To assess correlation between haemodynamic and CA responses to tracheal intubation, we plotted the changes in mean $B P, H R$, and plasma $C A$ concentrations in 60 children (Figure 4). Haemodynamic changes were well positively correlated with the CA changes.

\section{Discussion}

Laryngoscopy and tracheal intubation following intravenous induction with barbiturate is often accompanied by hypertension and tachycardia in children. ${ }^{1,2}$ We have confirmed these cardiovascular changes in the current study (active control group). A correlation between the haemodynamic responses associated with tracheal intubation and the changes in plasma CA concentrations in adults is well established. ${ }^{3-5}$ In particular, the increase in mean arterial pressure (MAP) following intubation correlates well with the increase in plasma NE concentration. ${ }^{16}$ The
TABLE I Demographic data of patients. Values are expressed as mean \pm SD.

\begin{tabular}{llcc}
\hline Groups & $\begin{array}{l}\text { Diazepam } \\
0.4 \mathrm{mg} \cdot \mathrm{kg}^{-1}\end{array}$ & $\begin{array}{l}\text { Clonidine } \\
2 \mu g \cdot \mathrm{kg}^{-1}\end{array}$ & $\begin{array}{l}\text { Clonidine } \\
4 \mu g \cdot \mathrm{kg}^{-1}\end{array}$ \\
\hline$n$ & 20 & 20 & 20 \\
Age (yr) & $10 \pm 1$ & $9 \pm 1$ & $10 \pm 1$ \\
Weight (kg) & $33 \pm 4$ & $30 \pm 3$ & $32 \pm 3$ \\
$\begin{array}{l}\text { Haemodynamics immediately } \\
\quad \text { before premedication }\end{array}$ & & & \\
- SBP (mmHg) & $98 \pm 5$ & $101 \pm 6$ & $103 \pm 6$ \\
- DBP (mmHg) & $57 \pm 4$ & $61 \pm 5$ & $61 \pm 6$ \\
- HR (beats/min) & $95 \pm 6$ & $93 \pm 6$ & $98 \pm 7$ \\
\hline
\end{tabular}

At any variables, $P>0.05$.

increase in plasma NE concentrations likely reflects the extent of NE release from the adrenal gland and adrenergic nerve endings (especially from the latter) in response to such sympathetic stimulation. ${ }^{17}$ Consistent with the previous reports in adults, ${ }^{3-5}$ we have confirmed the good correlation between haemodynamic and $\mathrm{CA}$ responses in children. However, the strongest correlation between MAP and NE changes was not observed in children. There seems to be no satisfactory explanation for this difference. Clonidine has been reported to inhibit central sympathetic outflow with the resultant suppression of CA release. ${ }^{18}$ These intubation-related haemodynamic and CA responses were attenuated by clonidine 4 $\mu \mathrm{g} \cdot \mathrm{kg}^{-1}$, but not by $2 \mu \mathrm{g} \cdot \mathrm{kg}^{-1}$. The precise reason for this is unknown. However, a recent study of adults undergoing cardiac surgery has shown that the effects of clonidine on haemodynamic variables and plasma CA levels are dose-related up to a dose of $4 \mu \mathrm{g} \cdot \mathrm{kg}^{-1} \cdot{ }^{19} \mathrm{An}$ other explanation for this difference in CA responses is proposed. We previously reported that $2 \mu \mathrm{g} \cdot \mathrm{kg}^{-1}$ clonidine requires a $33 \%$ greater induction dose of thiamylal than $4 \mu \mathrm{g} \cdot \mathrm{kg}^{-1}$ clonidine. $^{8}$ However, here we administered an identical dose of thiamylal to all children. The different CA responses may be due to the different depth of anaesthesia achieved in patients receiving the high and low doses of clonidine. For practical reasons, a placebo control group was not assigned in the current study. Thus, whether oral diazepam causes a smaller CA response to intubation in children than a placebo would remain to be determined. Although intravenous diazepam (0.2-0.3 $\left.\mathrm{mg} \cdot \mathrm{kg}^{-1}\right)$ has been shown to provide sedation resulting in or from inhibition of CA release in conscious adults, ${ }^{20}$ it is unlikely that oral diazepam (10 mg) premedication attenuates $\mathrm{CA}$ changes following intubation in adults. ${ }^{3-5}$

Thiamylal is a thiobarbiturate which is very similar to thiopentone in chemical structures and 1.1 times as 

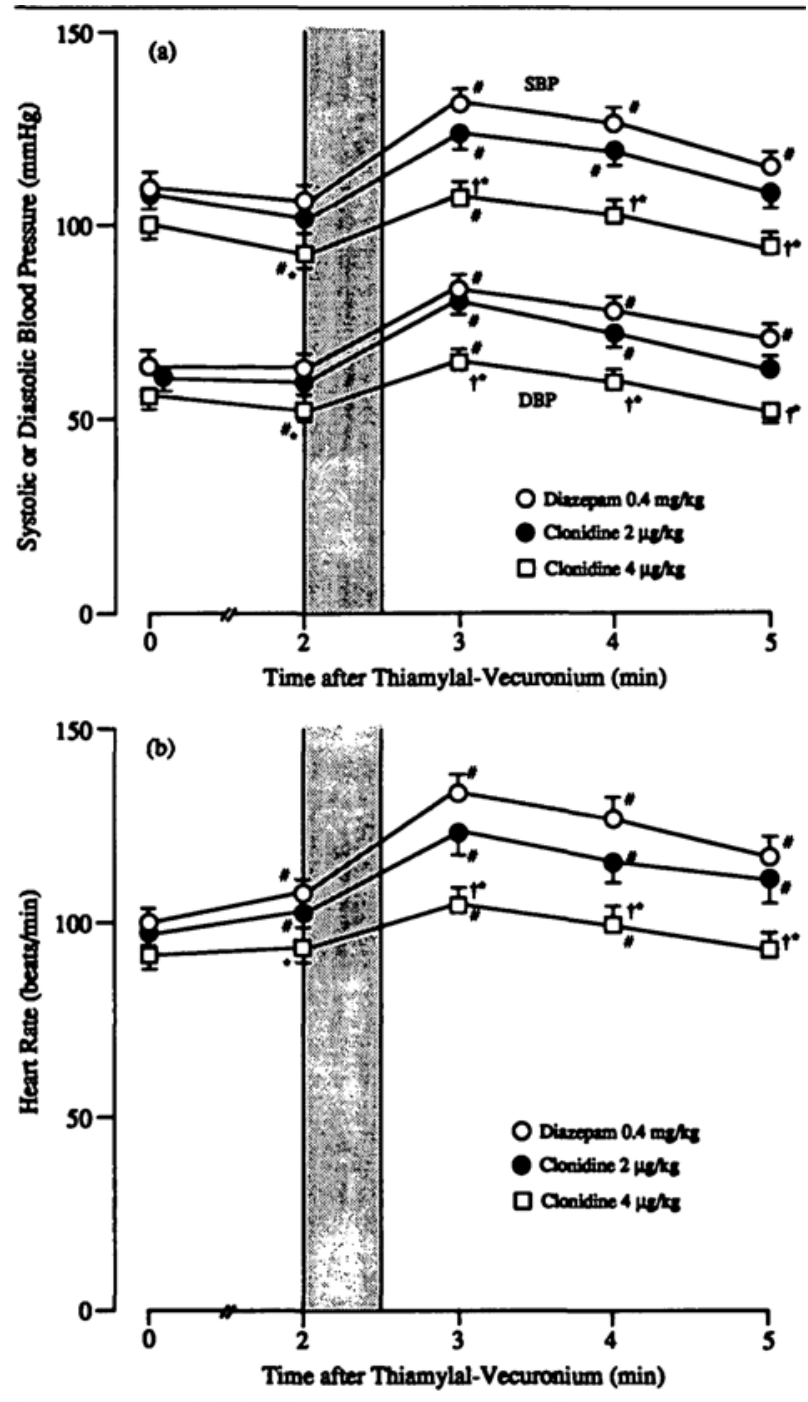

FIGURE 1 Haemodynamic changes (mean \pm SEM) after thiamylalvecuronium and in response to tracheal intubation with oral clonidine or diazepam premedication. The stippled area indicates the duration of laryngoscopy and tracheal intubation $(30 \mathrm{sec}$ ). (a) Blood pressure. SBP: systolic blood pressure, DBP: diastolic blood pressure. (b) Heart rate. $\# P<0.05$ vs operating room baseline ( $=$ immediately before induction) within groups, ${ }^{*} P<0.05$ vs diazepam, $\uparrow P<0.05$ vs 2 $\mu \mathrm{g} \cdot \mathrm{kg}^{-1}$ clonidine.

potent as thiopentone. ${ }^{21}$ Since two large-scale blinded studies found no difference between these drugs, ${ }^{22}$ the difference in potency seems to be too small to achieve no clinical importance. The recommended dose of thiamylal for induction of anaesthesia is similar to that of thiopentone in infants and children. ${ }^{23}$ Thus, we believe that the results of our study can be extrapolated to clinical setting where thiopentone is used.

In adults, the CA responses to tracheal intubation is the greatest in central venous samples compared with in arterial or peripheral venous samples. ${ }^{3}$ The lower CA
TABLE II Maximum percent changes in haemodynamics and plasma catecholamine concentrations associated with tracheal intubation. Values are expressed as mean $\pm \mathrm{SEM}$.

\begin{tabular}{lccr}
\hline & $\begin{array}{c}\text { Diazepam } \\
0.4 \mathrm{mg} \cdot \mathrm{kg}^{-1}\end{array}$ & $\begin{array}{l}\text { Clonidine } \\
2 \mu g^{\cdot} \mathrm{kg}^{-1}\end{array}$ & $\begin{array}{c}\text { Clonidine } \\
4 \mu \mathrm{gg}^{\cdot} \mathrm{kg}^{-1}\end{array}$ \\
\hline Mean blood pressure & $28 \pm 2$ & $26 \pm 2$ & $13 \pm \mathrm{I}^{* \dagger}$ \\
Heart rate & $38 \pm 4$ & $30 \pm 3$ & $8 \pm 1^{* \dagger}$ \\
$\begin{array}{l}\text { Epinephrine concentrations } \\
\text { Norepinephrine } \\
\text { concentrations }\end{array}$ & $293 \pm 26$ & $243 \pm 32$ & $51 \pm 4^{* \dagger}$ \\
\hline
\end{tabular}

$* P<0.05$ vs diazepam group.

$\dagger P<0.05$ for clonidine $4 \mu \mathrm{g} \cdot \mathrm{kg}^{-1}$ vs clonidine $2 \mu \mathrm{g} \cdot \mathrm{kg}^{-1}$.

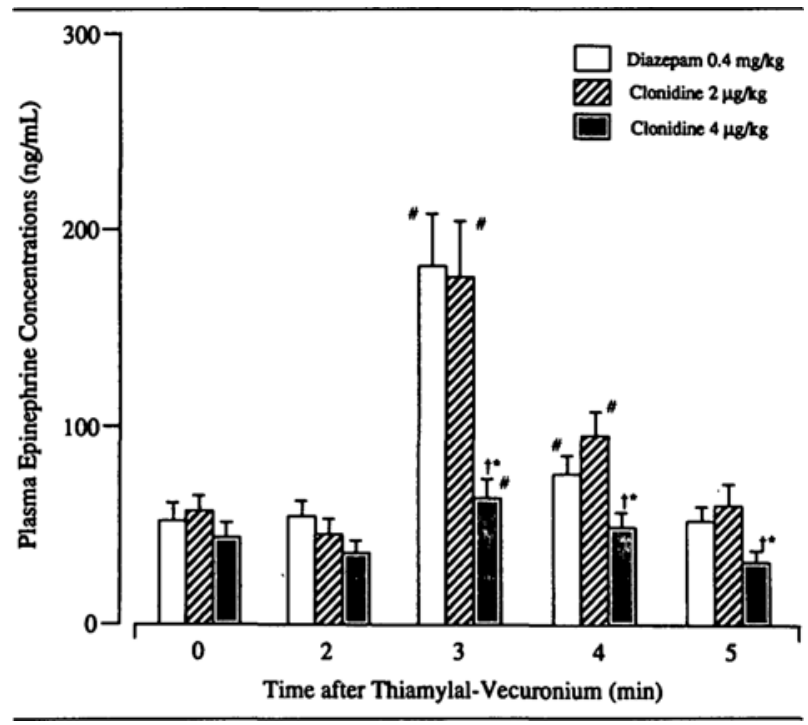

FIGURE 2 Changes in plasma epinephrine concentrations (mean \pm SEM) after thiamylal-vecuronium and in response to tracheal intubation with oral clonidine or diazepam premedication. $\# P<0.05$ vs operating room baseline (= immediately before induction) within groups, ${ }^{*} P<0.05$ vs diazepam, $\dagger P<0.05$ vs $2 \mu \mathrm{g} \cdot \mathrm{kg}^{-1}$ clonidine.

response in the latter two sampling sites may be due to the first pass effect through the lung. Blood collection from the central vein may have elicited more prominent difference in CA changes among the three groups compared with that from the artery or peripheral vein. However, patterns of CA response are similar regardless of sampling site. ${ }^{3}$ Furthermore, central venous cannulation is not ethical or feasible in awake children undergoing minor surgery.

Many techniques have been devised to reduce the extent of cardiovascular responses to intubation in adults, including the use of opioids, lidocaine, adrenergic blocking agents, and vasodilating agents. ${ }^{24}$ However, a limited number of drugs for this purpose have been studied in children, ${ }^{1,2}$ because hypertension and tachycardia following tracheal intubation are of no clinical relevance in 


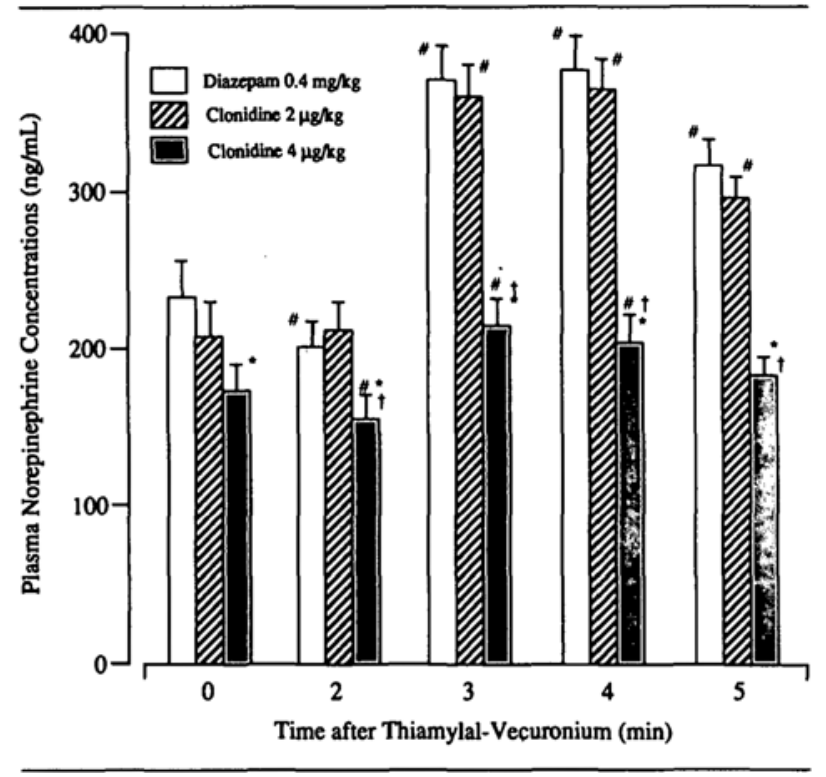

FIGURE 3 Changes in plasma norepinephrine concentrations (mean \pm SEM) after thiamylal-vecuronium and in response to tracheal intubation with oral clonidine or diazepam premedication. $\# P<0.05$ vs operating room baseline (= immediately before induction) within groups, ${ }^{*} P<0.05$ vs diazepam, $\dagger P<0.05$ vs $2 \mu \mathrm{g} \cdot \mathrm{kg}^{-1}$ clonidine.
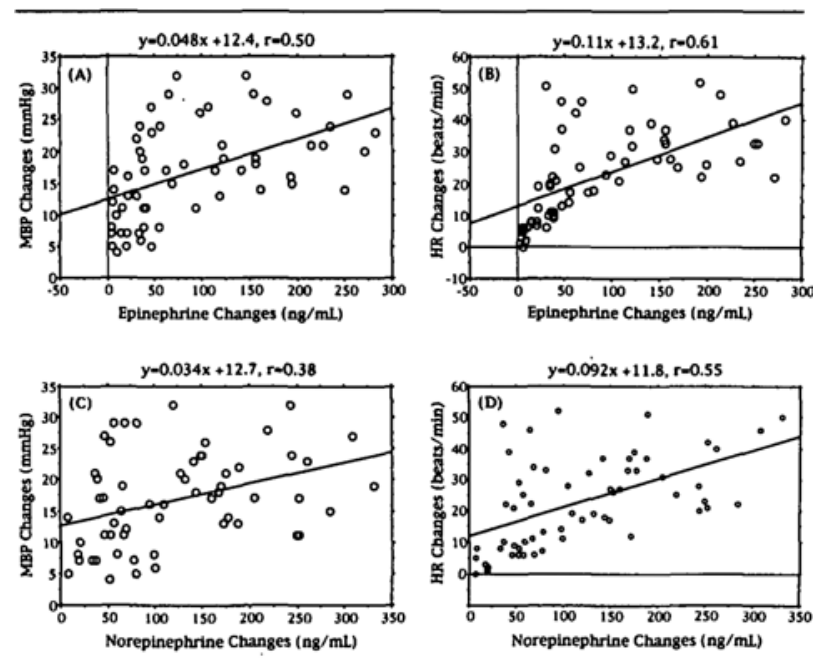

FIGURE 4 Correlation between haemodynamics and plasma catecholamines changes following tracheal intubation. (A) Correlation between mean blood pressure (MBP) and epinephrine changes; (B) correlation between heart rate (HR) and epinephrine changes; (C) correlation between MBP and norepinephrine changes; and (D) correlation between $\mathrm{HR}$ and norepinephrine changes. MBP was calculated using the following formula: $\mathrm{MBP}=1 / 3$ (SBP-DBP) + DBP, where SBP and DBP are systolic and diastolic blood pressure, respectively. (A)-(D): $P<0.05$.

healthy children. It should be noted that Splinter studied the effect of fentanyl (successful attenuation) ${ }^{1}$ or lidocaine (unsuccessful attenuation) $^{2}$ on these cardiovascular re- sponses in children based on his concern that this population is also at risk of developing complications, such as cerebral vascular accidents and cardiac dysrhythmias, secondary to an excessive sympathetic response. Such paediatric patients would include children with hypertension due to renovascular disease or renal failure, those with cerebral arteriovenous malformations, and those with aortic insufficiency. Clonidine may successfully control haemodynamic changes following intubation in children at risk for these complications and may be more suitable than opioids because of the less depressive effect on respiration. ${ }^{25}$ Premedication with clonidine has been shown to improve haemodynamic stability in adults undergoing coronary artery bypass surgery. ${ }^{26}$ The effect of preoperative oral clonidine in children with coronary artery disease (e.g., Kawasaki syndrome) deserves further study.

Clonidine alone may cause bradycardia. In the current study, however, basal haemodynamic values in the three groups were comparable. We believe that these haemodynamic measurements may be ameliorated by oral atropine given as a second premedicant. The use of anticholinergic premedication in paediatric anaesthesia is decreasing. We regarded the safety of the current study as important since this study was one of preliminary investigations conducted to evaluate the various effects of clonidine in children. Thus, we used preoperative oral atropine concomitantly. We have recently administered $4 \mu \mathrm{g} \cdot \mathrm{kg}^{-1}$ clonidine to 32 children without oral atropine. ${ }^{27}$ In that study, no children receiving this high dose had bradycardia severe enough to require treatment. However, since the sample size was small $(n=32)$, further investigations of the necessity for oral atropine in children who are premedicated with clonidine should be undertaken.

Ambulatory surgery is increasing in children. Clonidine may be an impractical premedication in this group as it has a slow onset and a long duration of action. However, our experience of its safe and successful use in many paediatric inpatients suggests that this premedicant can be used for outpatients. In particular, clonidine may be useful for children requiring postoperative rest (e.g., those undergoing strabismus surgery). Further studies are needed to assess usefulness of clonidine in paediatric ambulatory surgery. A recent analytic study of the pharmacokinetic behaviour of rectal clonidine in children ${ }^{28}$ also encourages us to conduct the study for this assessment.

In conclusion, we have shown that tracheal intubation caused an increase in plasma CA concentrations, BP, and $\mathrm{HR}$ in children receiving diazepam, and that clonidine $4 \mu \mathrm{g} \cdot \mathrm{kg}^{-1}$ po blunted these changes. However, a lower dose of clonidine failed to do so. Attenuation of the pres- 
sor and tachycardiac responses to tracheal intubation with an oral high-dose of clonidine could be due at least in part to suppression of CA release. Further studies are required to verify whether this CA suppression resulting in attenuation of haemodynamic changes is exerted in children with hypertension (e.g., in hypertension arising from chronic renal failure).

\section{References}

1 Sims $\mathrm{CH}$, Splinter WM. Fentanyl blunts the haemodynamic response of children to laryngoscopy. Can $\mathbf{J}$ Anaesth 1990; 37: S91.

2 Splinter WM. Intravenous lidocaine does not attenuate the haemodynamic response of children to laryngoscopy and tracheal intubation. Can J Anaesth 1990; 37: 440-3.

3 Derbyshire DR, Chmielewski A, Fell D, Vater M, Achola $K J$, Smith G. Plasma catecholamine responses to tracheal intubation. Br J Anaesth 1983; 55: 855-60.

4 Crawford DC, Fell D, Achola KJ, Smith G. Effects of alfentanil on the pressor and catecholamine responses to tracheal intubation. Br J Anaesth 1987; 59: 707-12.

5 Shribman AJ, Smith G, Achola KJ. Cardiovascular and catecholamine responses to laryngoscopy with and without tracheal intubation. Br J Anaesth 1987; 59: 295-9.

6 Aantaa $R$, Scheinin $M$. Alpha 2 -adrenergic agents in anaesthesia. Acta Anaesthesiol Scand 1993; 37: 433-48.

7 Mikawa K, Maekawa N, Nishina K, Takao Y, Yaku H, Obara $H$. Efficacy of oral clonidine premedication in children. Anesthesiology 1993; 79: 926-31.

8 Nishina K, Mikawa K, Maekawa N, Takao Y, Obara H. Clonidine decreases the dose of thiamylal required to induced anesthesia in children. Anesth Analg 1994; 79: 766-8.

9 Wright PMC, Carabine UA, McClune S, Orr DA, Moore $J$. Preanaesthetic medication with clonidine. $\mathrm{Br} \mathrm{J}$ Anaesth 1990; 65: 628-32.

10 Nishikawa T, Dohi S. Oral clonidine blunts the heart rate response to intravenous atropine in humans. Anesthesiology 1991; 73: 217-22.

11 Steward DJ. Psychological preparation and premedication. In: Gregory GA (Ed.). Pediatric Anesthesia, 2nd ed. New York: Churchill Livingstone Inc., 1989: 523-38.

12 Krane EJ, Davis PJ, Smith RM. Preoperative preparation. In: Motoyama EK (Ed.). Smith's Anesthesia for Infants and Children, 5th ed. St. Louis: CV Mosby, 1990: 201-16.

13 Henderson JM, Spence DG, Komocar LM, Bonn GE, Stenstrom RJ. Administration of nitrous oxide to pediatric patients provides analgesia for venous cannulation. Anesthesiology 1990; 72: 269-71.

14 Krstulovic AM. Investigations of catecholamine metabolism using high-performance liquid chromatography. $\mathrm{J}$ Chromatogr 1982; 229: 1-34.

15 Causon RC, Carruthers ME. Measurement of catecholam- ines in biological fluids by high-performance liquid chromatography. J Chromatogr 1982; 229: 301-9.

16 Derbyshire $D R$, Smith $G$. Sympathoadrenal responses to anaesthesia and surgery. Br J Anaesth 1984; 56: 725-39.

17 Ganong WF. Review of Medical Physiology, 12th ed. Los Altos: Lange Medical Publications, 1985.

18 Waite $R$. Inhibition of sympathetic nerve activity resulting from central alpha-adrenoceptor stimulation. In: Milliez $P$, Safar M (Eds.). Recent Advances in Hypertension, vol. II. Reims: Boehringer Ingerheim, 1975: 27-35.

19 Kulka PJ, Tryba M, Zenz M. Dose-response effects of intravenous clonidine on stress response during induction of anesthesia in coronary artery bypass graft patients. Anesth Analg 1995; 80: 263-8.

20 Takaya $Y$. The study of endocrine action on psychosedation - comparative study between nitrous oxide inhalation sedation and diazepam intravenous sedation. Journal of Okayama Dental Society 1990; 9: 295-307.

21 Dundee JW. Molecular structure-activity relationship of barbiturates. In: Halsey MJ, Millar RA, Sutton JA (Eds.). Molecular Mechanisms in General Anaesthesia. New York: Churchill Livingstone Inc., 1974: 16-31.

22 Tovell RM, Anerson CC, Sadove MS, et al. A comparative clinical and statistical study of thiopental and thiamylal in human anesthesia. Anesthesiology 1955; 16: 910-26.

23 Barron DW, Dundee JW, Gilmore WR, Howard PJ. Clinical studies of induction agents. XVI: A comparison of thiopentone, buthalitone, hexobarbitone and thiamylal as induction agents. Br J Anaesth 1966; 38: 802-11.

$24 \mathrm{Ng}$ WS. Pathophysiological effects of tracheal intubation. In: Latto IP, Rosen M (Eds.). Difficulties in Tracheal Intubation. East Bourne: Baillière Tindall, 1985: 12-35.

25 Eisenach J, Detweiler D, Hood D. Hemodynamic and analgesic actions of epidurally administered clonidine. Anesthesiology. 1993; 78: $277-87$.

26 Liepert DJ, Townsend GE. Improved hemodynamic and renal function with clonidine in coronary artery bypass grafting. Anesth Analg 1990; 70: S240.

27 Nishina K, Mikawa K, Maekawa N, Obara H. Oral clonidine premedication blunted heart rate response to intravenous atropine in awake children. Anesthesiology 1995; 83: 1126-30.

28 Lönnqvist PA, Bergendahl HTG, Eksborg S. Pharmacokinetics of clonidine after rectal administration in children. Anesthesiology 1994; 81: 1097-101. 